\title{
MIĘDZY DOŚWIADCZENIEM A TEORIĄ, CZYLI O NIEKTÓRYCH PROBLEMACH FILOZOFII MISTYKI
}

W słynnym eseju z 1914 r., zatytułowanym Mysticism and Logic ${ }^{1}$ (pol. Mistycyzm i logika), znany brytyjski noblista Bertrand Russel pisał:

Metafizyka, która jest wysiłkiem podejmowanym dla objęcia za pomocą myślenia świata w jego całości, rozwijała się od początku dzięki połączeniu i dzięki konfliktowi dwóch ludzkich dążeń o bardzo różnym porządku, które popychają ludzi — jednych w kierunku mistycyzmu, innych — w kierunku nauki [...]. Najwięksi jednak spośród filozofów odczuwali podwójną potrzebę nauki i mistycyzmu. Wysiłek pogodzenia [obu dążeń — A.R.B.] — oto czym było ich życie. Właśnie w tym wysiłku kryje się to, co — zdaniem niektórych — sprawia, że filozofia w całej swej męczącej niepewności jest zarazem większa niż nauka i niż religia ${ }^{2}$.

Te słowa Russela (matematyka, logika, uznawanego także za jednego z najwybitniejszych filozofów XX wieku) wydają się istotne głównie przez to, co implikują - swoiste rozpoznanie filozofii jako obszaru właściwego dla prób ujęcia owego mistycznego dążenia, które ożywia poszukiwania wielu otwartych umysłów i niejednokrotnie ujawniało się w dziejach bądź jako fenomen

Dr hab. AlEKSANDER RYSZARD BAŃKA, prof. UŚ - Uniwersytet Śląski w Katowicach, Wydział Humanistyczny, Instytut Filozofii; adres do korespondencji: ul. Bankowa 11, 40-007 Katowice; e-mail: aleksander.banka@us.edu.pl; ORCID: https://orcid.org/0000-0003-1801-4710.

${ }^{1}$ Tekst dostępny w wersji internetowej: Bertrand RusseLL, Mysticism and Logic and Other Essays, Project Gutenberg, https://www.gutenberg.org/files/25447/25447-h/25447-h.htm.

${ }^{2}$ Przekład na podstawie wydania francuskiego: Bertrand Russel, Le Mysticisme et la Logique, trad. Jean de Menasce (Paris: Payot, 1922), 7-8. Tekst oryginalny: „Metaphysics, or the attempt to conceive the world as a whole by means of thought, has been developed, from the first, by the union and conflict of two very different human impulses, the one urging men towards mysticism, the other urging them towards science. [...] But the greatest men who have been philosophers have felt the need both of science and of mysticism: the attempt to harmonise the two was what made their life, and what always must, for all its arduous uncertainty, make philosophy, to some minds, a greater thing than either science or religion". 
niezależny, bądź współdany z poszukiwaniami naukowymi. Nie ulega wątpliwości, że każda próba intelektualnego opracowania tego dążenia obciążona jest pewnym ryzykiem, zwłaszcza że niejednokrotnie kulminuje ono w specyficznym typie doświadczenia, zwanego mistycznym, które, samo w sobie, rodzi liczne kontrowersje. Jak zauważa Stanisław Judycki:

najczęściej podnoszony zarzut $\mathrm{w}$ stosunku do możliwej roli takiego doświadczenia [...] głosi, że - o ile w ogóle takie doświadczenie istnieje — to jest ono intersubiektywnie niesprawdzalne i intersubiektywnie niekomunikowalne. Trzeba jednak zwrócić uwagę, że, po pierwsze, doświadczenia Boga pojawiają się u sporej grupy ludzi, a więc w tym sensie mogą być uznane za sprawdzalne. Po drugie, $\mathrm{z}$ tego, że coś jest intersubiektywnie niekomunikowalne, nie wynika, że coś nie istnieje lub że jest fałszywe [...]. Ludzi dysponujących doświadczeniem mistycznym $\mathrm{w}$ powyższym sensie można by porównać do tej nielicznej grupy, która w społeczeństwie widzących wyłącznie w odcieniach szarości, byłaby zdolna do widzenia barwnego. Tego rodzaju doświadczenia są także „przeniknięte” rozumem, gdyż jak inaczej można byłoby je ująć dla siebie i — przynajmniej częściowo - relacjonować innym? $?^{3}$.

Co więcej, także William James w swej książce Odmiany doświadczenia religijnego (The Varieties of Religious Experience) zwraca uwagę na fakt, że doświadczenia mistyczne, choć przypominają ulotne i niewyrażalne stany uczuciowe, wydają się jednocześnie stanami poznania, dają bowiem niedyskursywny wgląd w głębiny prawdy, przyjmując często postać pełnych wagi oraz znaczenia iluminacji lub objawień ${ }^{4}$. Czy fakt ten nie wydaje się wystarczającym powodem, aby zajęła się nimi także filozofia? Wydaje się więc, że przekonanie Russela o jej niebagatelnej roli w odniesieniu do obu typów dążeń - naukowego i mistycznego - mimo że wyrażone ponad sto lat temu, nie straciło wciąż nic ze swej aktualności. Dziś dodatkowo wzmacnia je fakt, że — jak zauważa Józef Baniak — „pytanie, czym w swej istocie i znaczeniu jest mistyka, ciągle jest pytaniem otwartym i ważnym problemem inspirującym różnych badaczy do szukania adekwatnych wyjaśnień i określeń jej specyfiki. Skali tego problemu są świadomi wybitni znawcy religii i mistyki"s. Warto więc przyjrzeć mu się nieco bliżej z perspektywy, którą daje filozofia.

\footnotetext{
${ }^{3}$ Stanisław JUDYCKI, Bóg i inne osoby. Próba z zakresu teologii filozoficznej (Poznań: W drodze, 2010), 30-31.

${ }^{4}$ Por. William JAMES, Odmiany doświadczenia religijnego, przeł. Jan Hempel (Warszawa: Aletheia, 2011), 344.

${ }^{5}$ Józef BANIAK, „Mistyka - jej istota, rodzaje, funkcje, tło religijne i kulturowe”, w: Filozofia religii, t. 5: Mistyka jako stan świadomości i typ doświadczenia religijnego, red. Józef Baniak (Poznań: Wydawnictwo UAM, 2009), 7.
} 


\section{FILOZOFIA MISTYCZNA CZY FILOZOFIA MISTYKI?}

O ścisłych związkach filozofii z mistycyzmem czy też z mistyką pisał, oczywiście, nie tylko Bertrand Russel. Na ich istnienie wskazuje również w swej książce Wprowadzenie do filozoficznej mistyki niemiecki filozof Karl Albert, podkreślając, że w toku historii ludzkiego ducha mistyka i filozofia wielokrotnie się łączyły ${ }^{6}$. Co więcej, aby właściwie uchwycić ich wzajemne powiązania, należy usunąć leżące na tej drodze przeszkody, do których Albert zalicza: po pierwsze, uprzedzenie, że mistyka i filozofia nie mają z sobą nic wspólnego; po drugie, przekonanie, że wszelkie mistyczne doświadczenie odsłania się tylko jako prywatne przeżycie u nielicznych, odznaczających się szczególnymi uzdolnieniami ludzi; po trzecie, przesąd, że wypowiedzi filozofujących mistyków są niejasne i bałamutne ${ }^{7}$. Mirosław J. Gontarski zwraca uwagę na fakt, że mistyczne tezy zawarte były już w myśli Pitagorasa, którego filozofia wywarła nieoceniony wpływ na sposób widzenia świata i niektóre zaistniałe po nim systemy filozoficzne ${ }^{8}$. Nie dziwi zatem fakt, że Karl Albert łączy z sobą te dwa porządki - filozoficzny oraz mistyczny i posługuje się terminem „filozoficzna mistyka”, podkreślając konieczność wydobycia pierwotnego i przewodniego motywu filozofowania, w myśl przekonania Fryderyka Nietzschego, że właściwym celem wszelkiego filozofowania jest intuitio mystica ${ }^{9}$. W gruncie rzeczy chodzi bowiem także o to, na ile filozoficzna mistyka mogłaby realizować się jeszcze jako filozofia mistyczna, a na ile stać się filozofią mistyki. Jest to rozróżnienie klasyczne, ugruntowane w dziejach rozwoju mistyki. Filozofia mistyczna stawia bowiem w centrum indywidualne doświadczenie konkretnego mistyka, w ramach którego określone kategorie filozoficzne są nie tylko eksploatowane teoretycznie, ale również $\mathrm{w}$ pewien sposób przeżywane; posiadają, jak pisze Kazimierz Rynkiewicz, swoiste „zabarwienie mistyczne”10. W ten sposób termin „filozofia mistyczna” stanowiłaby, mutatis mutandis, aplikację na szerszy teren filozoficzny tego, co w odniesieniu do samego Boga oznaczała u Pseudo-Dionizego „teologia mistyczna”, czyli pewien rodzaj doświadcze-

\footnotetext{
${ }^{6}$ Por. Karl Albert, Wprowadzenie do filozoficznej mistyki, przeł. Józef Marzęcki (Kęty: Daimonion, 2002), 5.

${ }^{7}$ Por. ibidem, 6.

${ }^{8}$ Por. Mirosław J. GONTARSKI, „O przypadkach bezpośredniego kontaktu umysłu z najwyższą prawdą w doświadczeniach mistycznych jednostek ludzkich”, w: Filozofia religii, t. 5, 336.

${ }^{9}$ Por. AlBert, Wprowadzenie, 5.

${ }^{10}$ Por. Kazimierz RYNKIEWICZ, „Filozofia mistyczna, czy raczej mistyka filozoficzna? Założenia antropologiczne mistyki i filozofii Karola Wojtyły", Kultura i Wartości 11 (2015), 1: 6.
} 
nia poznawczego - najwyższy szczebel ciemnego i tajemnego poznania, w którym podmiot $\mathrm{w}$ sposób nad-substancjalny i poza-komunikowalny wchodzi w zjednoczenie z Niewyrażalnym ${ }^{11}$. Czy uprawiana $w$ takim duchu filozoficzna mistyka znajduje dziś rację bytu? Z kolei przejście od filozoficznej mistyki do filozofii mistyki wymagałoby potraktowania filozofii jako narzędzia swego rodzaju metarefleksji nad rozmaitymi doświadczeniami uznanymi za mistyczne. Tym razem jednak owa refleksja zmierzałaby nie tylko do ich systematycznego wyartykułowania, ale także do teoretycznego opisu i sukcesywnej eksplikacji — aż po mniej lub bardziej kompletną teorię owych doświadczeń, opartą na analizie problemowej, abstrahującej od przywiązania do indywidualnego, lokalnego doświadczenia pojedynczego mistyka. Tak rozumiana metarefleksja przyjmowałaby zatem kształt ujęcia szerszego, indukowanego, co prawda, z przeżyć wybranych mistyków, lecz stosującego się ostatecznie bądź do wszystkich, bądź do wybranej grupy doświadczeń mistycznych, jako tłumaczące je, spekulatywne opracowanie; wówczas jednak byłaby już teorią doświadczenia mistycznego jako takiego.

Współczesne interakcje między filozofią a doświadczeniem mistycznym — przynajmniej w obszarze filozofii zachodniej — przebiegają zasadniczo i raczej będą przebiegały bardziej na polu filozofii mistyki niż na polu filozofii mistycznej. Dużą rolę odgrywa pod tym względem fakt, że filozofia mistyczna powinna być uprawiana wyłącznie przez mistyków, filozofia mistyki zaś niekoniecznie. Nie jest to, wbrew pozorom, wcale oczywiste, a nawet wywołuje niejednokrotnie wyraźną kontestację. Wystarczy chociażby przywołać w tym miejscu słowa Leszka Kołakowskiego, który swego czasu stwierdził wprost: „Niepodobna analizować mistyków, nie będąc samemu mistykiem albo nie mając przynajmniej za sobą doświadczeń mistycznych. Inaczej mamy sytuację taką, jak gdyby głuchy chciał uprawiać krytykę muzyczną"12. Choć pogląd Kołakowskiego jest mocno dyskusyjny, to jednak nie ulega wątpliwości, że ujęcie doświadczenia mistycznego w sytuacji, gdy badacz nie ma do niego bezpośredniego dostępu, jest bardzo problematyczne. Niestety, jak zauważa Józef Baniak, doświadczenie to ,jest niepowtarzalne, a zawsze sytuacyjne, czyli zawsze ma ono miejsce «tu i teraz», nie da się go «odtworzyć» nigdzie indziej, pod jakimkolwiek pretekstem"13.

\footnotetext{
${ }^{11}$ Por. Edyta STEIN, „Drogi poznania Boga”, w: EADEM, Drogi poznania Boga. Studium o Dionizym Areopagicie i przekład jego dzieł, przeł. Grzegorz Sowiński (Kraków: Wydawnictwo Karmelitów Bosych, 2006), 64-65; 69.

${ }^{12}$ Leszek KoŁAKOwSKI, Świadomość religijna i więź kościelna. Studia nad chrześsijaństwem bezwyznaniowym XVIII wieku (Warszawa: Wydawnictwo Naukowe PWN, 1997), 34.

${ }^{13}$ Por. BANIAK, „Mistyka”, 12-13.
} 
Zawsze więc, przywoływane po fakcie, jest już nieco innym doświadczeniem, problem tylko, jak bardzo innym i na ile jego opis odbiega od samego doświadczenia źródłowego. Niewątpliwie te właśnie kwestie stanowią jeden z głównych obszarów problemowych filozofii mistyki. Pewne jednak jest i to, że wątpliwości, które powstały i wciąż powstają na tym terenie, nie zdołały powstrzymać nie-mistyków przed próbami zgłębienia natury doświadczenia mistycznego. W sposób naukowy zajmowały się nim więc rzesze filozofów - podobnie zresztą jak i przedstawicieli innych dyscyplin naukowych. Trudno nie zgodzić się z tym, że filozofia mistyki uprawiana przez nie-mistyków jest faktem, niezależnie od tego, jaka pozostaje rzeczywista wartość sformułowanych przez nich wniosków. Tym samym słynne przekonanie Ewagriusza z Pontu, że kto nie widział Boga, nie może o nim mówić ${ }^{14}$, choć wciąż nieodparcie pociąga tajemnym urokiem, straciło jednak swój apodyktyczny charakter. Pewna dziejowa prawidłowość, a zwłaszcza metodologiczne wymogi współczesnej nauki, nieuchronnie przesuwają akcent z filozofii mistycznej w kierunku filozofii mistyki. Już w średniowieczu duże zasługi miała w tym względzie szkoła kanoników regularnych ze Świętego Wiktora, w tym zwłaszcza dwaj czołowi jej przedstawiciele - Hugon i Ryszard. To właśnie wysiłki wiktorynów otwierają w rozwoju mistyki właściwy okres scholastyczny, powodując, że na filozofię mistyczną nakłada się filozofia mistyki; na opis nakłada się system ${ }^{15}$. Można więc postawić pytanie, czy aby takie właśnie zadanie nie staje dziś, między innymi, przed refleksją filozoficzną? Czy w takim zakresie, w jakim uczyni ona przedmiotem swych zainteresowań doświadczenie mistyczne, może - jako filozofia mistyki właśnie — wnieść swój wkład w rozjaśnienie natury tego doświadczenia? Jeżeli tak jest $\mathrm{w}$ istocie, to musi ona nieuchronnie zmierzyć się z pewnymi problemami metodologicznymi, przed którymi stanie zresztą każda dyscyplina naukowa, próbująca wedrzeć się do wnętrza mistyki ze swym spragnionym rozumienia nastawieniem. Jednym z nich jest problem interpretacji samego pojęcia mistyki i rozmaitych prób jego systematyzacji.

${ }^{14}$ Por. Joseph Maréchal, ,Vers la théologie mystique du Pseudo-Denys. Points de comparaison dans la mystique grecque du $\mathrm{IV}^{\mathrm{e}}$ siècle", w: IDEM, Études sur la Psychologie des Mystiques, t. 2 (Paris: Desclée de Brouwer et Compagnie, 1937), 22.

${ }^{15}$ Por. Joseph MARÉCHAL, „Les tournants principaux dans l'histoire de la mystique catholique", w: IDEM, Études, 8. 


\section{WOKÓŁ PROBLEMU SYSTEMATYZACJI}

Pojawia się zatem pytanie, czym jest samo doświadczenie mistyczne. Od razu też, niestety, trzeba przyznać rację Piotrowi Moskalowi, który w swym artykule „Mistyka jako przedmiot filozofii religii” pisze tak: „Nie ma żadnego, powszechnie akceptowanego rozumienia terminu «mistyka» ani zgody co do tego, co jest mistyką, które teksty są mistyczne, które osoby są mistykami, na czym polegają stany mistyczne" ${ }^{\prime 6}$. Nie znaczy to jednak, że w tej kwestii panuje całkowita dowolność. Grzegorz Strzelczyk pisze:

Po pierwsze, chodzi w mistyce o taki kontakt jednostki z Absolutem [...], który podmiot przeżywa jako bezpośredni. Bezpośredniość należy tu rozumieć w skrajnym znaczeniu - wykluczającym nie tylko pośrednictwo osób trzecich, przedmiotów, znaków i systemów (rytów i języka), ale również samych pojęć (nawet myśl nie staje między mistykiem a Bogiem) [...]. Warto już w tym miejscu zauważyć, że „przedmiotem” doświadczenia mistycznego jest Bóg ${ }^{17}$.

Stanisław Judycki zaś precyzuje, że chodzi o doświadczenie Boga i (niektórych) Jego atrybutów ${ }^{18}$. Sęk w tym, że to, co obecnie kryje się pod pojęciem mistyki, dawno już wykroczyło poza tak rozumiany obszar przedmiotowy. Właściwie, jak tłumaczy Joseph Sudbrack, można przyjąć, że nie istnieje dziś chyba dziedzina kultury, w której nie mówiłoby się o mistyce - czy to chociażby w obszarze muzyki, literatury, teorii systemów, biologii, astrofizyki, gospodarki, polityki, a zwłaszcza religii ${ }^{19}$. Co więcej, termin „mistyka” staje się elementem najbardziej przedziwnych konstrukcji znaczeniowych, począwszy od tak prozaicznych, jak mistyka sportu, kuchni, zakupów czy też mistyka prędkości, aż po subtelniejsze, filozoficzne sposoby jego stosowania, jak mistyka świata, Boga czy też mistyka $j a^{20}$. Trzeba niestety uznać, że sprawy nie rozwiązuje w tym względzie odwołanie do źródłowego znaczenia terminu „mistyka”. Jak zauważa Grzegorz Strzelczyk, „różnice istnieją już na poziomie opinii, co do etymologii samego terminu «mistyka», bowiem niektórzy badacze wywodzą go zdecydowanie $\mathrm{z}$ hellenistycznych korzeni, inni [...] chcieliby widzieć u jego korzeni Pawłowe pojęcie «misterium»"21. Z kolei

${ }^{16}$ Piotr MosKaL, „Mistyka jako przedmiot filozofii religii”, w: Filozofia religii, t. 5, 17.

${ }^{17}$ Grzegorz StrZelCzYK, „Fenomen mistyki”, w: Mistyka chrześcijańska, red. Janusz Wilk (Katowice: Księgarnia św. Jacka, 2015), 13.

${ }^{18}$ Por. JUDYCKI, Bóg, 30.

${ }^{19}$ Por. Joseph SudBrack, Mistyka, przeł. Bernard Białecki (Kraków: WAM, 1996), 8.

${ }^{20}$ Por. Joseph MARÉCHAL, „Vraie et fausse mystique”, Nouvelle revue théologique 67 (1945): $275-281$.

${ }^{21}$ STRZELCZYK, „Fenomen”, 12-13. Por. także: James WisEMAn, Historia duchowości chrześcijańskiej, przeł. Andrzej Wojtasik (Kraków: WAM, 2009), 25-26. 
Piotr Moskal, zwraca uwagę na fakt, że zarówno „mistycyzm”, jak i „mistyka" są to terminy stosunkowo nowe. Ten pierwszy wszedł w użycie prawdopodobnie dopiero $\mathrm{w}$ pierwszej połowie XVIII wieku jako określenie czegoś nadzwyczajnego, pokrewnego ekstazie, drugi powstał w siedemnastowiecznej Francji na określenie prywatnych objawień i nadzwyczajnych doznań psychosomatycznych ${ }^{22}$. Czy wyczerpuje się w nich dzisiejsze rozumienie mistycznego doświadczenia? Oczywiście — nie. Co więcej, William James zwraca również uwagę na fakt, że współcześnie tego rodzaju terminów „często używa się w znaczeniu nagannym wobec mniemania, które uważamy za niejasne, mgliste, sentymentalne i nieoparte ani na faktach, ani na logice. Dla niektórych pisarzy «mistyk» to ktoś wierzący w telepatię lub wywoływanie duchów. Wyraz ten używany w taki sposób ma niewielką wartość, 23 .

O wiele dłuższą tradycję niż „mistyka” i „mistycyzm” ma z kolei przymiotnik „mistyczny”, który wywodzi się z greckiego słowa $\mu v \sigma \tau$ «óv [mystikón], stosującego się pierwotnie do sfery rozmaitych misteriów. W takim właśnie znaczeniu termin ten został przejęty przez tradycję chrześcijańską i odniesiony właśnie do wspomnianego już chrześcijańskiego „misterium”,

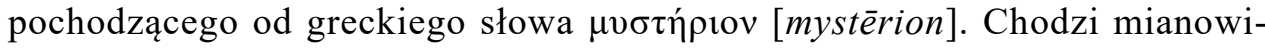
cie o rozmaite formy nadprzyrodzonej partycypacji w tajemnicy Boga, takie jak prawdy objawione, liturgia, sakramenty, katecheza, kontemplacja. Niestety bardzo szybko ten pierwotny kontekst znaczeniowy poszerzył się także w łonie samego chrześcijaństwa - a w efekcie przymiotnik „mistyczny" został włączony w rozmaite, często wzajemnie wykluczające się konteksty $^{24}$. Wciąż jednak wskazuje on na pewne rozumienie podstawowe - co prawda niezwykle szerokie i mało precyzyjne, ale jednak dominujące mianowicie na świadomość spotkania czy zjednoczenia z jakąś różnie rozumianą rzeczywistością ostateczną ${ }^{25}$. Właśnie w oparciu o taką perspektywę podejmowano i nadal się podejmuje próby rozmaitych systematyzacji mistyki, chcąc jak najadekwatniej uchwycić ową fundującą doświadczenie mistyczne rzeczywistość ostateczną. Proponowane systematyzacje dokonywane są zazwyczaj w oparciu o jakąś formę typologii. I tak, na przykład Walter T. Stace próbuje systematyzować mistykę pod kątem możliwych typów świadomości mistycznej, wyróżniając, po pierwsze, świadomość ekstrawertyczną, polegającą na poczuciu jedności wszystkich rzeczy, po drugie - świado-

\footnotetext{
${ }^{22}$ Por. MosKal, „Mistyka”, 17.

${ }^{23}$ JAMES, Odmiany, 343.

${ }^{24}$ Por. MosKal, „Mistyka”, 18-19; MARÉCHAL, „Vraie et fausse mystique”, 275.

${ }^{25}$ Por. Moskal, „Mistyka”, 18; Wiseman, Historia, 28.
} 
mość introwertyczną, polegającą na poczuciu pustej beztreściowej jedności samej świadomości oczyszczonej $\mathrm{z}$ wszelkiej treści ${ }^{26}$. Wspólnymi cechami ekstrawertycznego doświadczenia mistycznego — jak pisze Bernard McGinn, komentując stanowisko Stace'a - są:

jednoczący ogląd (wszystkie rzeczy są jednym), szczególnego rodzaju ujęcie Jednego jako życia we wszystkich rzeczach, poczucie obiektywności i realności, szczęśliwość i pokój [...]. Wspólne cechy wyższej formy introwertycznego doświadczenia mistycznego, do którego dąży doświadczenie ekstrawertyczne, to: czysta lub zjednoczona świadomość, nieprzestrzenność i nieczasowość, szczęśliwość i pokój, odczucie świętości, paradoksalność i deklarowana niewysłowionośćc ${ }^{27}$.

Problem, który rodzi powyższa systematyzacja, polega chociażby na tym, że co prawda stosunkowo dobrze stosuje się ona do tych odmian mistyki, które u swych podstaw mają jakąś formę metafizyki o charakterze panteistycznym, zdecydowanie trudniej zaadaptować ją jednak do mistyki relacyjnej, osobowej, w której poczucie jedności wszechrzeczy lub poczucie jedności świadomości jako takiej - jeśli występuje - to tylko jako pokłosie zjednoczenia z Bogiem. Zjednoczenie to jest bowiem rozumiane w sposób relacyjny, a więc nie przez zlanie, stopienie, ale - jak utrzymuje na przykład św. Jan od Krzyża - przez uczestniczące posiadanie Boga ${ }^{28}$. Czy jest to kwestia wyłącznie terminologiczna, czy też różnica faktycznie zachodząca w samej naturze doświadczenia mistycznego? To między innymi stanowi przedmiot dyskusji toczonej przez filozofów mistyki i nie tylko.

Nieco inne trudności rodzi z kolei systematyzacja zaproponowana przez Roberta C. Zaehnera, który wyodrębnia określone typy doświadczeń mistycznych i na tej podstawie wyróżnia mistykę panenheniczną (polegającą na poczuciu jedności z kosmosem), mistykę monistyczną (czyli mistykę jaźni) oraz mistykę teistyczną (to znaczy mistykę Bożą, polegającą na doświadczeniu osobowego Boga) ${ }^{29}$. Jak zaznacza Bernard McGinn, Zaehner jest zwolennikiem poglądu, że istnieje wielość rodzajów mistyki ${ }^{30}$ - wynika to wyraźnie z zaproponowanej przez niego systematyzacji, która z tego między innymi względu przysporzyła i jemu, i wielu podobnie myślącym badaczom

\footnotetext{
${ }^{26}$ Por. MosKal, „Mistyka”, 18.

${ }^{27}$ Bernard McGinN, Fundamenty mistyki, przeł. Tomasz Dekert (Kraków: Wydawnictwo Uniwersytetu Jagiellońskiego, 2009), 451-452.

${ }^{28}$ Por. JAN OD KRZYŻA, „Żywy płomień miłości”, w: IDEM, Dzieła, przeł. Bernard Smyrak (Kraków: Wydawnictwo Karmelitów Bosych, 1995), 755; 792-793, punkt 34; 78.

${ }^{29}$ Por MosKaL, ,Mistyka”, 18.

${ }^{30}$ MCGinn, Fundamenty, 457.
} 
licznych oponentów. Dodatkowa trudność łączy się z faktem, że część badaczy mistyki ma w zwyczaju angażować filozofię głównie na polu mistyki naturalnej i w takim duchu operuje pojęciem, którym posługiwał się między innymi Karl Albert — pojęciem filozoficznej mistyki. Zaehnerowska systematyzacja zmusza poniekąd do postawienia pytania, jak powinna kształtować się relacja filozofii do mistyki określonej mianem teistycznej. Mieczysław Gogacz, podając konkretne racje przemawiające za tym, że pozostają one z sobą w ścisłym związku, utrzymuje, że filozofia powinna angażować się wszędzie tam, gdzie w doświadczeniu mistycznym dałoby się wyróżnić jego elementy metafizyczne, ontologiczne, epistemologiczne, etyczne, estetyczne bądź antropologiczne ${ }^{31}$. Siłą rzeczy pojawia się więc pytanie o właściwy dla filozofii, mistyczny obszar przedmiotowy. Konieczność wyodrębnienia takiego obszaru wydaje się zupełnie oczywista. Bez tego filozof mistyki czy jakikolwiek inny jej badacz nieuchronnie ugrzęźnie w zalewie fenomenów, których nie sposób ogarnąć w usystematyzowany sposób, tym bardziej że — jak zauważa Joseph Maréchal — pod etykietą mistyki ukrywa się obecnie stany często do siebie nieprzystające - zarówno duchowe zachwycenia Teresy z Awila, jak i halucynacje palaczy haszyszu ${ }^{32}$. „Czy to wszystko - pyta z kolei Joseph Sudbrack — jest mistyką?" ${ }^{33}$. Oczywiście przykłady faktycznych bądź quasi-mistycznych doświadczeń można by mnożyć. Aby jednak próbować w jakikolwiek sposób je ocenić i sklasyfikować, potrzeba definicji mistyki lub przynajmniej określonego sposobu zawężenia jej pola do pewnego typu fenomenów kluczowych kojarzonych z tak zwanym twardym jądrem mistyki. Fakt ten generuje kolejny problem metodologiczny - problem konieczności dookreślenia natury doświadczenia mistycznego tak, aby precyzyjniej wskazać, czym ono jest i w jakim zakresie udostępnia się badaniom filozofii mistyki.

\footnotetext{
${ }^{31}$ Mieczysław Gogacz, koncentrując się przede wszystkim na metafizyce teistycznej (chrześcijańskiej), pisze: „Wszyscy teoretycy mistyki i sami mistycy podkreślają, że w doświadczeniu mistycznym doświadcza się Boga, właśnie bezpośrednio i że się wie, iż to jest bezpośrednie spotkanie z Bogiem. Dyskutuje się natomiast przebieg doświadczenia mistycznego, pytanie o to, jaką sferą swego bytu człowiek doświadcza Boga, po czym poznać, że to jest właśnie doświadczenie Boga, a nie innego bytu, i w związku z tym dyskutuje się, kim jest Bóg. Większość tych dyskutowanych zagadnień, ze względu na pytanie; czym coś jest, należy do filozofii. Pytamy bowiem, czym jest doświadczenie mistyczne, kim jest Bóg, jakim procesem w człowieku jest doświadczenie". Mieczysław GogaCz, Filozoficzne aspekty mistyki. Materiały do filozofii mistyki (Warszawa: Wydawnictwo UKSW, 1985), 11.

${ }^{32}$ Por. Joseph MARÉCHAL, „Réflexions sur l'étude comparée des mysticismes”, w: IDEM, Études, 414.

${ }^{33}$ SudBraCK, Mistyka, 7.
} 


\section{OD FENOMENU DO STRUKTURY}

Precyzyjne zdefiniowanie mistyki jako takiej jest, niestety, praktycznie niemożliwe. Dzieje się tak, po pierwsze, ze względu na pluralizm doświadczeń uznawanych za mistyczne i wielość nadawanych im znaczeń, po drugie natomiast z powodu samej hermeneutyki terminu „mistyka” oraz dodatkowego wpływu kontekstów religijnych i kulturowych ${ }^{34}$. Stwierdza to również Bernard McGinn, podkreślając, że „możliwość stworzenia jakiejkolwiek prostej definicji tak złożonego i kontrowersyjnego fenomenu wydaje się raczej utopijna"35. Pojawia się zatem pytanie, czy można uchwycić jego naturę na inny niż definicyjny sposób. Joseph Sudbrack proponuje w tym kontekście określony sposób postępowania, zmierzający do wydobycia z całego spektrum zjawisk składających się na domniemane przeżycie mistyczne tych właśnie, które pozwalają wyświetlić jego mistyczną swoistość. Chodzi mianowicie o spojrzenie na fenomenalny wymiar doświadczenia mistycznego pod czterema różnymi kątami - Sudbrack nazywa je czterema drogami. Pierwszą z nich byłaby droga psychologiczna, która ujawnia pewną bierność doświadczenia mistycznego i współdane z nią właściwości specyfikujące, takie jak poczucie dali, nieskończoności, spokoju, tożsamości, spełnienia, pewności, a także pasywny wgląd $\mathrm{w}$ istotę rzeczy oraz zdolność do wyższego rodzaju syntezy ${ }^{36}$. Analizując tę kwestię z perspektywy tradycji chrześcijańskiej, Grzegorz Strzelczyk pisze:

Co do sposobu relacjonowania się z Bogiem - wyróżnia się mistyka [...] pasywnościa [...]. Pasywność, o której mowa, nie równa się jednak całkowitemu brakowi aktywności podmiotu. Cała aktywność koncentruje się w doświadczeniu mistycznym na przyjmowaniu Boga [...]: kiedy wszystko jest przyjmowaniem, można przyjąć znacznie więcej, niż gdy podmiot dzieli uwagę woli między różne przedmioty ${ }^{37}$.

Za Maciejem Manikowskim wolno powiedzieć jeszcze tak:

Mistyczne zjednoczenie może nastąpić jedynie wtedy, kiedy dusza ludzka podda się całkowicie działaniu, aktywności przedmiotu doświadczenia [...], a to oznacza, że w kulminacyjnym momencie mistycznego spotkania [...] podmiot niejako zamiera, a działać zaczyna przedmiot doświadczenia ${ }^{38}$.

${ }^{34}$ Por. BANIAK, „Mistyka”, 7.

${ }^{35}$ McGinn, Fundamenty, XVI.

${ }^{36}$ Por. SUdBrack, Mistyka, 12.

${ }^{37}$ STRZELCZYK, „Fenomen”, 13-14.

${ }^{38}$ Maciej MANiKowsKi, „Mistyczne cechy doświadczenia religijnego”, w: Filozofia religii, t. 4: Doświadczenie religijne jako problem filozofii religii i teologii, red. Józef Baniak (Poznań: Wydawnictwo UAM, 2008), 86. 
To jednak, oczywiście, jeszcze zbyt mało, aby mówić o doświadczeniu mistycznym. Nie chodzi przy tym wyłącznie o fakt, że ową bierność, samą w sobie - oprócz przypisywanych jej cech — określa także pewien znamienny rodzaj świadomości, który łączy się, zdaniem Williama Jamesa, ze specyficznym pochwyceniem woli mistyka przez wyższa siłę ${ }^{39}$. Joseph Sudbrack stoi na stanowisku, że aby właściwie ująć fenomenalny wymiar doświadczenia mistycznego, trzeba uwzględnić jeszcze inne drogi postępowania, wyostrzające jego specyfikę i dopełniające pierwszą, psychologiczną drogę. Kolejną, jego zdaniem, jest droga historyczno-socjologiczna, która obok specyficznej bierności mistycznego doświadczenia pozwala wykryć pewien towarzyszący temu moment pierwotnego wzruszenia. Sudbrack ma na myśli taki jego rodzaj, który sięga prapoczątków doświadczenia religijnego w ogóle i potwierdza, że źródłowo, w tak zwanych religiach elementarnych, doświadczenia religijne i mistyczne były z sobą silnie zlane, a dopiero później się rozdzieliły, skutkując pewną elitaryzacją tego drugiego ${ }^{40}$. Według Stanisława Wszołka ich wspólną bazę stanowiło głębokie wyczucie sacrum, którym odznaczał się pierwotny człowiek, przeżywając otaczający go świat i wszelkie doświadczenia egzystencjalne jako uczestnictwo w rzeczywistości świętej, przekraczającej ograniczenia aktualnego miejsca i czasu ${ }^{41}$. Mircea Eliade mówi nawet o swoistej hierofanii - akcie przejawiania się świętości $\mathrm{w}$ archaicznych doświadczeniach religijnych ${ }^{42}$. Z kolei trzecia droga to, jak twierdzi Joseph Sudbrack, droga estetyczno-symboliczna, która do bierności i głębokiej warstwy pierwotnej wzruszeniowości doświadczenia mistycznego, dodawałaby jeszcze specyficzny fenomen estetyczny ${ }^{43}$. „W toku całej historii [...] - pisze Roland Maisonneuve - duchowi [ludzie - A.R.B.] i mistycy pozostający w żywej i ożywczej relacji z Bogiem, przekładali często swe doświadczenie w obrazy i symbole, które im się narzucały"44. Nie chodzi jednak bynajmniej o uchwycenie w narracji mistyka jej walorów artystycznych. Rzecz dotyczy kwestii umiejętnego rozpoznania w warstwie mistycznego przekazu śladów silnie zazwyczaj spoetyzowanego przeżycia symbolu, ujmowanego jednak nie na sposób alegorycznego wskaźnika, ale w jego źródłowej transparencji, w której odsłaniałaby się mistyczna osobliwość.

\footnotetext{
${ }^{39}$ Por. JAMES, Odmiany, 344-345.

${ }^{40}$ Por. SudBrack, Mistyka, 12-13.

${ }^{41}$ Stanisław WszoŁeK, Wprowadzenie do filozofii religii (Kraków: WAM, 2004), 58.

${ }^{42}$ Mircea Eliade, Sacrum, mit, historia, wyboru dokonał i wstępem opatrzył Marcin Czerwiński, przeł. Anna Tatarkiewicz (Warszawa: Państwowy Instytut Wydawniczy, 1974), 159-160.

${ }^{43}$ Por. SUDBRACK, Mistyka, 13-14.

${ }^{44}$ Roland Maisonneuve, Dieu inconnu, Dieu Trinité (Paris: Cerf, 2002), 10.
} 
Wreszcie droga czwarta, religijna, to zdaniem Sudbracka umiejętność uchwycenia faktu, że każde doświadczenie mistyczne wyrasta na glebie jakiegoś wyznania, przekonania bądź światopoglądu ${ }^{45}$. Fakt ten w fenomenalnej warstwie doświadczenia mistycznego przejawiałby się przeżyciem pewnego pietyzmu w stosunku do przedmiotu tego doświadczenia, choć niekoniecznie przeżyciem religijnym w sensie ścisłym. Droga religijna uznawałaby również pewną quasi-religijność, byłaby rodzajem przejmującego fascinosum czy też — jak pisze Mircea Eliade, powołując się na Rudolfa Otto - mysterium fascinans $^{46}$, którego ewentualny nie-religijny mistyk doświadczałby w odniesieniu do orientującej jego aktywność i odsłaniającej się w mistycznym doświadczeniu absolutnej podstawy jego wszelkich przekonań.

Oczywiście powyższe wyodrębnienie jest bardziej próbą poszukiwania niż definitywnym rozpoznaniem faktycznej, wspólnej wszystkim doświadczeniom mistycznym warstwy fenomenalnej. Jako takie odsyła ono również do pewnego strukturalnego fundamentu ujawniającego się w doświadczeniu mistycznym - fundamentu podmiotowo-przedmiotowego, na który wskazuje Sudbrack jako na podstawę każdego mistycznego fenomenu. Podobną strukturę akcentuje w doświadczeniu mistycznym Joseph Maréchal, wskazując na zachodzące $w$ nim zderzenie nieprzeniknionej głębi mistycznego przedmiotu z podmiotową otwartością na jego nieskończonośćc ${ }^{47}$. Ta, można by rzec, dwudzielna totalność, generowana przez podmiotowo-przedmiotową strukturę doświadczenia mistycznego, przebijając przez jego fenomenalną warstwę, w praktyce konstytuuje się jako doświadczenie całościowe i zarazem jako doświadczenie całości. Sudbrack przekonuje, że jako doświadczenie całościowe ujawnia się niejako po stronie podmiotowej mistyka, natomiast jako doświadczenie całości — po stronie przedmiotowej ${ }^{48}$. Znaczyłoby to, że każda fenomenalna składowa doświadczenia mistycznego kryje w sobie taką właśnie dwudzielność. W takim jednak swym uwarunkowaniu - i to jest niezwykle istotne - odsłania się wciąż jako pewien fakt psychologiczny. Zarówno bowiem doznanie owej podmiotowoprzedmiotowej totalności, jak i występowanie nabudowujących się na niej fenomenalnych składowych doświadczenia mistycznego, to wciąż fakty w obrębie ludzkiej psychiki. Problem polega na tym, że część badaczy mistyki chce je tam apriori pozostawić i tłumaczyć w oparciu o mechanizmy

\footnotetext{
${ }^{45}$ Por. SUdBRACK, Mistyka, 14-15.

${ }^{46}$ Por. Eliade, Sacrum, 159.

${ }^{47}$ Por. MARÉCHAL, „Vraie et fausse mystique”, 281-283.

${ }^{48}$ Por. SudBrack, Mistyka, 12.
} 
jedynie psychiczne. W konsekwencji tego rodzaju psychologizacja sprowadza fenomen mistyczny do poziomu intrapsychicznego, sprawiając, że traci on swą specyfikę, a nawet zostaje zinterpretowany w kluczu zaburzeń psychicznych lub psychosomatycznych. Przykładem mogą być niektóre tezy amerykańskiego psychologa Jamesa H. Leuby, którego zdaniem wszelkiego rodzaju mistyczne ekstazy (niezależnie od tego, na jakim gruncie doktrynalnym i w jakim kontekście kulturowym zachodzą) sprowadzają się ostatecznie do formy autohipnotycznego transu, gdzie hipnotyzer zastąpiony jest przez ideę Boga, a doświadczenie wewnętrznego ładu i duchowej harmonii, obecne często u mistyka po doświadczeniu ekstazy, do formy posthipnotycznej sugestii ${ }^{49}$. To jednak nie wszystko. Wiliam James pisze:

Kolejny krok ku stanom mistycznym wprowadza nas w dziedzinę, którą opinia publiczna i filozofia moralna od dawna piętnowały jako patologiczną [...]. Mam tu na myśli świadomość wywołaną przez środki odurzające i znieczulające [...]. Podtlenek azotu i eter, zwłaszcza ten pierwszy, gdy jest dostatecznie rozrzedzony powietrzem, nadzwyczaj pobudza świadomość mistyczną. Przed wdychającym zdają się otwierać całe głębiny prawdy. Prawda ta jednak blednie lub umyka, gdy się do niej zbliżyć, i jeśli pozostaje z niej kilka słów, w które zdawała się przyodziewać, to okazują się one najzwyklejszym nonsensem. Mimo to pozostaje wrażenie, że było tam jakieś głębokie znaczenie, i znam niejedną osobę przekonaną, że podczas odurzania podtlenkiem azotu doznajemy prawdziwego objawienia metafizycznego ${ }^{50}$.

Czy to znaczy, że doznania uznawane za mistyczne mają właśnie taką naturę? Czy można, ostatecznie, sprowadzić je do poziomu wytworów produkowanych przez świadomość pod wpływem środków halucynogennych? Nie należy, oczywiście, bagatelizować sytuacji, w których doświadczenie uznawane za mistyczne jest w istocie skutkiem działania jakiegoś środka odurzającego lub przejawem stanu chorobowego i można je wytłumaczyć za pomocą samych tylko funktorów czysto psychologicznych. Próba jednak uogólnienia takiego stanu rzeczy nie uwzględnia specyfiki doświadczenia mistycznego i jego bardzo złożonej hermeneutyki, a przede wszystkim roli ściśle skorelowanego z samym doświadczeniem podglebia doktrynalnego. Tymczasem w przekonaniu wielu badaczy mistyki to właśnie owo doktrynalne podglebie zdaje się odgrywać w doświadczeniu mistycznym niezwykle ważna rolę, nadając mu wartość głębszą niż ta, która wynika wyłącznie z czynników psychologicznych.

\footnotetext{
${ }^{49}$ James H. LeUBA, „Les tendances fondamentales des mystiques chrétiens”, Revue philosophique 54 (1902): 457-459.

${ }^{50}$ JAMES, Odmiany, 349-350.
} 


\section{ESENCJALIZM KONTRA KONTEKSTUALIZM}

Belgijski badacz mistyki Joseph Maréchal, polemizując z tymi, którzy $\mathrm{z}$ góry odrzucają $\mathrm{w}$ obrębie doświadczenia mistycznego jakikolwiek istotny związek między faktem psychologicznym a elementem doktrynalnym, pyta:

Jak można z góry wiedzieć, czy jakaś doktryna, narzucając się naszym wierzeniom niezależnie od wszelkiego osobistego objawienia, nie mogłaby a priori nadać mistycznej wartości pewnej grupie faktów wewnętrznych, których posiadane przez nie cechy empiryczne, same z siebie, nie odróżniałyby radykalnie od banalnych faktów psychologicznych? Ta doktryna konstytuowałaby pewną hiperontologię spekulatywny fundament mistyki ${ }^{51}$.

W ten sposób, zdaniem Maréchala, w obrębie jednego doświadczenia mistycznego fakt psychologiczny uzyskiwałby w doktrynie swe znaczenie transcendentne, doktryna zaś w fakcie - ekspresję psychologiczną ${ }^{52}$. Byłoby to możliwe dlatego, że właśnie w doktrynie mistycznej kryłby się impuls do fundamentalnej unifikacji wewnętrznej wielości psychologicznych faktów doświadczenia mistycznego w jedno spójne przeżycie, specyfikowane jednak kształtem owej doktryny. U podstaw takiego nastawienia tkwi przekonanie, że właściwa natura doświadczenia mistycznego ujawnia się dopiero w chwili, gdy uzna się, że zachodzące w świadomości mistyka, a nierzadko także przeniesione na jego somatyczność fenomeny nie wydarzają się tam $\mathrm{w}$ sposób izolowany. Znaczy to, że nie wydarzają się jako czyste fakty psychologiczne, ale w sprzęgnięciu z zapleczem doktrynalnym, z którego mistyk wyrasta i ku któremu intencjonalnie się orientuje. Stwierdza to zresztą wyraźnie między innymi Bernard McGinn, pisząc: „Żaden mistyk (przynajmniej do XX w.) nie wierzył w «mistykę» ani jej nie praktykował. Wyznawali i praktykowali oni chrześcijaństwo (lub też judaizm, islam czy hinduizm), to jest religie, które jako szersze zjawiska historyczne zawierały w sobie również elementy mistyczne" ${ }^{\text {}} 3$. Z tego też powodu Joseph Maréchal staje na stanowisku, że doświadczenie mistyczne jako takie kryje w sobie dwa elementy składowe: fakt psychologiczny w swym fenomenalno-strukturalnym ukonstytuowaniu oraz racjonalną lub objawioną doktrynę, co więcej — dopiero synteza tych dwóch elementów przekształca niejako fakt psychologiczny w fakt mistyczny ${ }^{54}$. Jakie są tego konsekwencje? Przede wszystkim

\footnotetext{
${ }^{51}$ Por. MARÉCHAL, „Réflexions”, 415-416.

${ }^{52}$ Por. ibidem, s. 416.

${ }^{53}$ MCGInN, Fundamenty, XVI-XVII.

${ }^{54}$ Por. MARÉCHAL, „Réflexions”, 415.
} 
takie, że — jak podkreśla Gershom Scholem — „nie ma mistyki jako takiej, istnieje natomiast mistyka czegoś, mistyka określonej religijnej formy: mistyka chrześcijaństwa, mistyka islamu, mistyka judaizmu i tym podobne" ${ }^{55}$. Przekonanie to wpisywałoby się w klasyczny spór o naturę doświadczenia mistycznego - spór między tak zwanym esencjalizmem a kontekstualizmem; rzecz jasna, jako argument na rzecz kontekstualizmu. Randolph T. Dible II pisze:

Ostatnie akademickie badania nad mistycyzmem są zakorzenione $\mathrm{w}$ ideologicznym starciu między dwiema szkołami interpretacji mistycyzmu: perenializmem (esencjalizmem lub dekontekstualizmem) $\mathrm{z}$ jednej strony i antyperenializmem (konstruktywizmem, intencjonalizmem lub kontekstualizmem) z drugiej. Pierwsza podtrzymuje uniwersalność mistycznego doświadczenia, podczas gdy druga uznaje je - podobnie jak, zdaniem jej przedstawicieli, każde inne ludzkie doświadczenie - całkowicie warunkowo ${ }^{56}$.

Można, oczywiście, polemizować z zaproponowaną przez Dible'a rekapitulacją stanowiska kontekstualistów (zwłaszcza z tezą o głoszonej przez nich całkowitej warunkowości stanów mistycznych), nie jest to jednak w tej chwili najistotniejsze. W gruncie rzeczy chodzi bowiem o różnicę, którą w następujący sposób określa Piotr Sztajer:

Esencjalizm głosi, że poza różnymi reprezentacjami, interpretacjami, wypowiedziami mistyków, istnieje pewien wspólny zbiór doświadczeń, które nie zależą od kontekstu społeczno-kulturowego. Obserwowane różnice między doświadczeniami pochodzącymi z różnych tradycji religijnych mają jedynie powierzchniowy charakter, w głębi zaś istnieje wspólne jądro wszelkiej mistyki ${ }^{57}$

— rodzaj czystej, pozbawionej wszelkich kulturowych uwarunkowań świadomości mistycznej. Takie podejście w toku dyskusji nad doświadczeniem mistycznym niejednokrotnie prowadziło do różnego rodzaju intelektualnych uproszczeń. Randolph T. Dible II pisze o tym wprost, przy okazji analizy kontekstualizmu:

Jego historyczne pojawienie się było wymuszone przez szerzącą się epistemologiczną naiwność i akademicką nieodpowiedzialność przeważającej literatury mistycznej perenializmu. Największy problem z niektórymi wpływowymi dzie-

${ }^{55}$ Gershom SCHOLEM, Die jüdische Mystik in Hauptströmungen, cyt. za: SuDBRACK, Mistyka, 8.

${ }^{56}$ Randolph T. DiBle II, „The Philosophy of Mysticism: Perennialism and Constructivism”, Journal of Consciousness Exploration \& Research 2, 1 (2010): 173.

${ }^{57}$ Sławomir SzTAJER, „Prywatny i publiczny język mistyki”, w: Filozofia religii, t. 5, 110. 
łami literatury perenialistycznej dotyczył ich bezkrytycznego (co najmniej) przedstawienia oryginalnych źródel ${ }^{58}$.

W podejściu esencjalistycznym zaproponowana przez samych mistyków doktrynalna interpretacja ich własnego doświadczenia jest bowiem traktowana jako coś zasadniczo różnego od przeżycia mistycznego, a zarazem jest wobec niego wtórna, ponieważ samo przeżycie w pełni konstytuuje się poza nią $^{59}$ i de facto może być ubierane w szatę dowolnych interpretacji. Zwolennikami takiego podejścia, głoszącymi teorię wspólnego rdzenia wszystkich doświadczeń mistycznych, choć - trzeba to zaznaczyć - często różnie rozumianego, byli między innymi William James, Walter T. Stace, John Hick, Ninian Smart (jego stanowisko jest dość niejednoznaczne), William Wainwright, Philip Almond ${ }^{60}$. Zdaniem jednak Piotra Sztajera „esencjalizm nie bierze pod uwagę faktu, że doświadczenie nie dokonuje się w próżni, lecz jest każdorazowo zakorzenione w kulturowym (doktrynalnym, mistologicznym, filozoficznym itd.) kontekście, w którym znajduje się mistyk" ${ }^{\text {" }}$. Inaczej kontekstualizm, reprezentowany zwłaszcza przez Roberta C. Zaehnera, Johna N. Findlaya, Josepha Maréchala, Petera Moore'a, Stevena T. Katza czy Gershoma Scholema ${ }^{62}$. W swej radykalniejszej wersji (jako konstruktywizm) głosi, że doświadczenie mistyczne konstytuuje się źródłowo jako już zinterpretowane, ponieważ — w przekonaniu konstruktywistów od samego początku jest ściśle powiązane $\mathrm{z}$ interpretacją narzuconą przez przekonania religijne i cały kontekst kulturowy, czyli — ogólnie rzecz ujmując - przez podglebie doktrynalne ${ }^{63}$. Z tego powodu, jak zauważa Dible, „konstruktywizm ma swe własne problemy. Zakłada się, że mistycyzm w sposób istotny warunkują koncepcje socjolingwistyczne [...]. Dla sensu i znaczenia mistycyzmu — podkreśla tymczasem Dible — jest kluczowe, że faktycznie są w nim czyste, niezapośredniczone, nieuwarunkowane doświadczenia i co więcej, jest to na tyle weryfikowalne w bezpośrednim doświadczeniu, na ile tylko możliwe" ${ }^{64}$. Pojawia się jednak pytanie, na jakiej podstawie Dible tak właśnie rozpoznaje ów element kluczowy. W ujęciu konstruktywistycznym rzeczywiście zostaje osłabiona pozapojęciowość

\footnotetext{
${ }^{58}$ DiBle II, The Philosophy of Mysticism, 177.

${ }^{59}$ Por. SzTAJer, „Prywatny i publiczny”, 111.

${ }^{60}$ Por. McGinn, Fundamenty, 450-459.

${ }^{61}$ Por. SzTAJer, ,Prywatny i publiczny”, 112.

${ }^{62}$ Por. MCGinn, Fundamenty, 454-461.

${ }^{63}$ Por. SzTAJer, „Prywatny i publiczny”, 112.

${ }^{64}$ DiBle II, The Philosophy of Mysticism, 177.
} 
i niepojmowalność doświadczenia mistycznego. Z kolei w wersji umiarkowanej kontekstualizm staje na stanowisku, że doświadczenie mistyczne, choć zawsze podlega interpretacji, to jednak interpretacja jest względem niego czymś wtórnym - nie jest z nim tożsama ${ }^{65}$. Zgodnie z takim modelem myślenia można by powiedzieć za Mirceą Eliadem, że

najwznioślejsze posłanie religijne, najbardziej uniwersalne $\mathrm{z}$ doświadczeń mistycznych $[\ldots]$ z chwilą wystąpienia nabierają cech szczegółowych i podlegają ograniczeniom. Gdy Syn Boży wcielił się i stał się Chrystusem, musiał mówić po aramejsku, musiał zachowywać się jak Hebrajczyk owej epoki, nie zaś jak jogin, taoista lub szaman. Jego posłanie religijne przy całej swej uniwersalności, było uwarunkowane przez minioną i aktualną historię ludu hebrajskiego ${ }^{66}$.

Spostrzeżenie to, przeniesione na teren filozofii mistyki, znaczyłoby dla kontekstualisty, że doświadczenie mistyczne nie jest od razu expressis verbis zinterpretowane, ale ,interpretowalne”, czyli w sposób konieczny podatne na interpretację według określonego klucza doktrynalnego, z którego wyrasta i poza którym pozostaje niezrozumiałe. Wynikałoby $\mathrm{z}$ tego, że choć doświadczenie to wydarza się poza wyraźnymi strukturami pojęciowymi, to jednak, w pewnym zakresie, pozwala się w owe pojęcia przetransponować, i to przetransponować w określony sposób.

W przeciwieństwie zatem do stanowiska esencjalistycznego, które w skrajnej postaci zakłada, że doświadczenie mistyczne może być wyrażone w oparciu o rozmaite, nawet radykalnie się różniące klucze interpretacyjne, kontekstualizm utrzymuje, że dla określonego doświadczenia klucz jest jeden, co więcej - że jest $\mathrm{z}$ góry prefigurowany w naturze samego doświadczenia. Owa prefiguratywność spowodowana jest faktem, że kontekst doktrynalny, z którego wyrasta mistyk, w pewnym sensie zapowiada domyślny kształt doświadczenia, ku którem mistyk aspiruje, co więcej — niejednokrotnie definiuje także środki prowadzące do jego osiągnięcia. W efekcie pojawia się następująca kwestia: Skoro zaplecze doktrynalne dla przyszłego mistyka stanowią na przykład takie filozoficzne bądź religijne systemy panteistyczne, które widzą w doświadczeniu mistycznym rodzaj dekonstruującego osobowość poczucia wszechjedności, co więcej — skoro proponują one określone, służące do tego celu narzędzia, to czy po osiągnięciu takiego doświadczenia mistyk mógłby wyrazić je w afirmujących osobowość, relacyjnych kategoriach personalistycznej mistyki teizmu? Zdaniem esencjalisty — tak, ponie-

\footnotetext{
${ }^{65}$ Por. SzTAJER, „Prywatny i publiczny”, 112.

${ }^{66}$ Eliade, Sacrum, 36.
} 
waż zarówno teista, jak i panteista doświadczają w gruncie rzeczy tego samego, a tylko wtórnie inaczej to wyrażają. „Nie ma logicznie nieodpartego powodu - pisze Philip Almond — dla którego chrześcijanin nie mógłby mieć [mistycznego - A.R.B.] doświadczenia hindusa, choć uznaje się, że są przekonujące, warunkowe przyczyny tego, że nie zdarza się to często",67. Z kolei zdaniem kontekstualisty nie jest to możliwe, ponieważ różnica nie zachodzi na poziomie samej tylko późniejszej interpretacji, ale na poziomie doświadczenia. Chrześcijanin świadomie i autentycznie przeżywający swą wiarę nie będzie miał doznań typowych dla hinduisty, ponieważ inaczej orientuje się jego duchowy wektor, inny jest cel jego wewnętrznej aktywności i treść, która ową aktywność organizuje. Przesądza o tym kontekst doktrynalny, w którym chrześcijanin — podobnie jak przedstawiciel każdej innej tradycji religijnej lub filozoficznej - wzrasta i który ów cel obiektywnie prefiguruje w teorii, zanim w takim czy innym stopniu stanie się on subiektywnie dostępny w duchowej praktyce mistyka. Steven T. Katz stwierdza:

Hinduistyczny mistyk nie ma doświadczenia $x$, które późnej opisuje w znanym sobie języku i symbolach, lecz raczej ma doświadczenie hinduistyczne, tj. nie stanowi ono jakiegoś niezapośredniczonego $x$, ale samo w sobie, przynajmniej częściowo, jest przed-ukształtowanym [pre-formed] antycypowanym hinduistycznym doświadczenie Brahmana. Z kolei chrześcijański mistyk nie doświadcza jakiejś niezidentyfikowanej realności, którą później wygodnie etykietuje jako Boga, ale raczej posiada przynajmniej częściowo prefigurowane chrześcijańskie doświadczenie Boga lub Jezusa, lub tym podobne ${ }^{68}$.

Nie wynika z tego bynajmniej, że Brahman, jako bezosobowy aspekt absolutu, rzeczywiście istnieje, podobnie jak wiele innych możliwych absolutów, co $\mathrm{w}$ praktyce skutkowałoby daleko posuniętym relatywizmem. Znaczy to jedynie, że doświadczenie hinduistycznego mistyka jest skutkiem zorientowania na pewien typ absolutu prefigurowanego w pojęciu Brahmana i że jeśli zachodzi — niezależnie od tego, czym faktycznie jest - nie pokrywa się z doświadczeniami na gruncie tradycji chrześcijańskiej. Kwestią wtórną pozostaje, na ile zasadnie zaliczane jest ono do doświadczeń mistycznych wtórną, bo zależną od zakresu znaczeniowego nadawanego każdorazowo pojęciu mistyki. Metodologiczny rygoryzm nakazuje oczywiście, aby te same uwagi zastosować również do mistyki chrześcijańskiej oraz do każdego

\footnotetext{
${ }^{67}$ Philip Almond, „Mysticism and its contexts”, 27 (1988), 1 (April): 43.

${ }^{68}$ Steven T. KATZ, „Language, Epistemology, and Mysticism”, w: Mysticism and Philosophical Analysis, red. Steven T. Katz (New York: Oxford University Press, 1978), 26.
} 
innego rodzaju mistyki. Kontekstualista zatem, inaczej niż esencjalista, jest przekonany, że mimo licznych podobieństw wynikających ze wspólnoty ludzkiej natury, panteistyczne i teistyczne systemy filozoficzno-religijne generują ostatecznie inne doświadczenia. Kto zatem ma rację? Lub raczej: czy spór ten w jakikolwiek sposób może zostać definitywnie rozstrzygnięty? Sławomir Sztajer prognozuje, że nie — przede wszystkim dlatego, że ani w jednym, ani w drugim przypadku nie występuje możliwość skonfrontowania ich twierdzeń z rzeczywistością ${ }^{69}$. Można jednak ostrożnie postawić pytanie, czy nie jest to prognoza zbyt pesymistyczna. Wszak przecież jeden z czołowych przedstawicieli esencjalizmu, Philip Almond, pisze:

Studium mistycznych tekstów postępowało zgodnie z założeniem, że wszystkie one, w mniejszym lub większym stopniu, były zróżnicowanymi przejawami tego samego doświadczenia lub tak bardzo zróżnicowanymi przejawami ograniczonej liczby doświadczeń ${ }^{70}$.

Kontekstualista z pewnością nie zgodzi się z tezą, że wielość rozmaitych opisów mistycznych byłaby de facto wariacją na temat jednego wspólnego, podstawowego doświadczenia. $Z$ dużo większym prawdopodobieństwem przychyli się jednak do tezy, że mogłyby one stanowić przejaw kilku jego fundamentalnych, nieredukowalnych do siebie typów. Czy w takiej sytuacji esencjalizm, który dopuściłby w tej kwestii pewien pluralizm i kontekstualizm, który taki pluralizm zdecydowałby się ograniczyć, nie zbliżają się do siebie? Pytanie tylko, jak wyznaczyć akceptowalną w obrębie obu stanowisk miarę. Problem jest oczywiście złożony. Steven T. Katz pisze:

Nasze badanie sugeruje, co sugeruje, szeroki wachlarz mistycznych doznań, które są, przynajmniej w odniesieniu do niektórych aspektów determinujących, kulturowo i ideologicznie ugruntowane ${ }^{71}$,

\section{a Bernard McGinn zauważa:}

Wydaje się, że przeprowadzona przez Katza krytyka idei wspólnego rdzenia doświadczenia mistycznego, jak również jego sprzeciw wobec [...] rozumienia języka mistycznego jako paradoksalnego [...] stanowiły dla współczesnej filozofii mistyki cios w czułe miejsce. Wskazuje na to różnorodność polemik i krytyk, z jaką spotkało się jego ujęcie ${ }^{72}$.

\footnotetext{
${ }^{69}$ Por. SzTAJER, „Prywatny i publiczny”, 113.

${ }^{70}$ ALmOND, „Mysticism”, 41.

${ }^{71}$ KATZ, „Language”, 66.

${ }^{72}$ MCGinN, Fundamenty, 463.
} 
Może więc należy jednak uczynić krok w tył, unikając pochopnego optymizmu. Piotr Sztajer główny powód braku konsensusu upatruje właśnie $\mathrm{w}$ kwestiach powiązanych z językiem mistyki. Pisze on:

Chociaż esencjalista powołuje się na bezpośrednie doświadczenia, a więc świadectwa niejako z pierwszej ręki, jedynym przedmiotem, jakim dysponuje podczas uzasadniania swoich przekonań, są sprawozdania z doświadczenia, które zawsze — inaczej być nie może — wyrażone są w jakimś języku i sformułowane za pomocą pojęć $[\ldots]$. W nie lepszej sytuacji pod tym względem znajduje się kontekstualista, który również nie ma wglądu w bezpośrednie przeżycie mistyka ${ }^{73}$.

W konsekwencji spór wokół problemu struktury doświadczenia mistycznego, a więc, w praktyce, dyskusja nad jego wymiarem fenomenalnym i kontekstem doktrynalnym generuje następną trudność metodologiczną — problem opisu doświadczenia mistycznego, czyli jego komunikatywności i komunikowalności. Co więcej, nie jest to jedyna nowa trudność. Okazuje się bowiem, że kolejne problemy narastają niemal proporcjonalnie do intensywności badawczego wnikania w świat mistyki, ukazując coraz to nowe pola niejasności i odsłaniając dalsze obszary niewiedzy. Czy zatem wysiłek filozofii mistyki jest poznawczo jałowy i z góry skazany na beznadziejne błąkanie się w żywiole niepoznawalnego? Otóż niekoniecznie. Wydaje się bowiem, że jeśli nawet filozofia mistyki nie zdoła nigdy pozytywnie i adekwatnie ująć natury doświadczenia mistycznego, to jednak, paradoksalnie, odsłaniając niuanse, problemy i trudności piętrzące się przed próbami takiego ujęcia, niejako na drodze negatywnej będzie w stanie doświadczenie to przybliżyć. Byłby to zarazem swoisty powrót do korzeni samej filozofii — bardziej do stawiania otwierających na mądrość pytań niż do formułowania mądrościowych odpowiedzi. Może okazałoby się wówczas, że właśnie w taki sposób spełnia się to, co swego czasu, mutatis mutandis, zapowiedział Tomasz z Akwinu jako pewien epistemiczny paradoks, a zarazem ideał: Deum tamquam ignotum cognoscimus — „poznajemy Boga jako nieznanego"74? Wszak, ostatecznie, jak pisał nieznany autor XIV-wiecznego dzieła mistycznego pt. Obłok niewiedzy:

Wszystkie istoty rozumne, a zatem aniołowie i ludzie, posiadają dwie władze władzę poznania i władzę kochania. Dla pierwszej władzy, rozumu, Bóg, który ją

${ }^{73}$ SzTAJER, Prywatny i publiczny, 113-114.

${ }^{74}$ Za: Tomasz Merton, „Wspinaczka ku prawdzie”, w: IDEM, Szukanie Boga, przeł. Piotr Parlej (Kraków: Wydawnictwo Karmelitów Bosych, 1983), 101. 
stworzył, jest na wieki niepoznawalny, dla drugiej jednak, miłości, jest w pełni poznawalny, i to dla miłości każdego poszczególnego człowieka ${ }^{75}$.

Aby tak było, filozoficzna refleksja musiałaby jednak, w rzeczywistości, zatoczyć swoisty krąg, a filozofia mistyki — na powrót stać się filozofią mistyczną.

\section{BIBLIOGRAFIA}

Albert, Karl. Wprowadzenie do filozoficznej mistyki. Przełożył Józef Marzęcki. Kęty: Daimonion, 2002.

Almond, Philip. „Mysticism and its contexts”. Sophia 27 (1988), 1 (April): 40-49. DOI: http://dx.doi.org/10.1007/BF02781310.

BANIAK, Józef. 2009. „Mistyka - jej istota, rodzaje, funkcje, tło religijne i kulturowe”. W: Filozofia religii. T. 5: Mistyka jako stan świadomości i typ doświadczenia religijnego, red. Józef Baniak, 7-15. Poznań: Wydawnictwo UAM.

Dible II, Randolph Thompson. „The Philosophy of Mysticism: Perennialism and Constructivism". Journal of Consciousness Exploration \& Research 2 (2010), 1: 173-183. https://www.researchgate.net/publication/265579493_The_Philosophy_of_Mysticism_Peren nialism_and_Constructivism

Eliade, Mircea. Sacrum, mit, historia. Wyboru dokonał i wstępem opatrzył Marcin Czerwiński. Przełożyła Anna Tatarkiewicz. Warszawa: Państwowy Instytut Wydawniczy, 1974.

Gogacz, Mieczysław. Filozoficzne aspekty mistyki. Materiaty do filozofii mistyki. Warszawa: Wydawnictwo UKSW, 1985.

GONTARSKI, Mirosław Jerzy. „O przypadkach bezpośredniego kontaktu umysłu z najwyższą prawdą w doświadczeniach mistycznych jednostek ludzkich”. W: Filozofia religii. T. 5: Mistyka jako stan świadomości i typ doświadczenia religijnego, red. Józef Baniak, 335-343. Poznań: Wydawnictwo UAM, 2009.

JAMES, William. Odmiany doświadczenia religijnego. Przełożył Jan Hempel. Warszawa: Aletheia, 2011.

JAN OD KRZYŻA. „Żywy płomień miłości”. W: IDEM. Dzieła. Przełożył Bernard Smyrak, 715-803. Kraków: Wydawnictwo Karmelitów Bosych, 1995.

JuDYCKI, Stanisław. Bóg i inne osoby. Próba z zakresu teologii filozoficznej. Poznań: W drodze, 2010.

KATZ, Steven Theodore. „Language, Epistemology, and Misticism”. W: Mysticism and Philosophical Analysis, red. Steven Theodore Katz, 22-74. New York: Oxford University Press, 1978.

KoŁAKOWSKI, Leszek. Świadomość religijna i więź kościelna. Studia nad chrześcijaństwem bezwyznaniowym XVIII wieku. Warszawa: Wydawnictwo Naukowe PWN, 1997.

LEUBA, James Henry. „Les tendances fondamentales des mystiques chrétiens”. Revue philosophique 54 (1902): 1-36, 441-487.

Maisonneuve, Roland. Dieu inconnu, Dieu Trinité. Paris: Cerf, 2002.

MANIKOWSKI, Maciej. „Mistyczne cechy doświadczenia religijnego”. W: Filozofia religii. T. 4: Doświadczenie religijne jako problem filozofii religii $i$ teologii, red. Józef Baniak, 75-87. Poznań: Wydawnictwo UAM, 2008.

\footnotetext{
${ }^{75}$ Obłok niewiedzy, przeł. Wojciech Unolt (Poznań: W drodze 2001), 39.
} 
MARÉCHAL, Joseph. „Les tournants principaux dans l'histoire de la mystique catholique”. W: IDEM. Études sur la Psychologie des Mystiques. T. 2, 3-16. Paris: Desclée de Brouwer et Compagnie, 1937.

MARÉCHAL, Joseph. „Réflexions sur l'étude comparée des mysticismes”. W: IDEM. Études sur la Psychologie des Mystiques. T. 2, 411-483. Paris: Desclée de Brouwer et Compagnie, 1937.

MARÉCHAL, Joseph. „Vers la théologie mystique du Pseudo-Denys. Points de comparaison dans la mystique grecque du IV ${ }^{\mathrm{e}}$ siècle”. W: IDEM. Études sur la Psychologie des Mystiques. T. 2, 91-141. Paris: Desclée de Brouwer et Compagnie, 1937.

MARÉCHAL, Joseph. „Vraie et fausse mystique”. Nouvelle revue théologique 67 (1945): 275-295.

McGinn, Bernard. Fundamenty mistyki. Przełożył Tomasz Dekert. Kraków: Wydawnictwo Uniwersytetu Jagiellońskiego, 2009.

Merton, Tomasz. „Wspinaczka ku prawdzie”. W: IDEM. Szukanie Boga. Przełożył Piotr Parlej, 9-258. Kraków: Wydawnictwo Karmelitów Bosych, 1983.

MoskaL, Piotr. „Mistyka jako przedmiot filozofii religii”. W: Filozofia religii. T. 5: Mistyka jako stan świadomości $i$ typ doświadczenia religijnego, red. Józef Baniak, 17-25. Poznań: Wydawnictwo UAM, 2009.

Obłok niewiedzy. Przełożył Wojciech Unolt. Poznań: W drodze, 2001.

Russell, Bertrand, Mysticism and Logic and Other Essays, London: George Allen \& Unwin LTD, 1917, Project Gutenberg, dostęp 2.03.2020, https://www.gutenberg.org/files/25447/ 25447-h/25447-h.htm.

Russel, Bertrand. Le Mysticisme et la Logique. Traduction Jean de Menasce. Paris: Payot, 1922.

RYNKIEWICZ, Kazimierz. „Filozofia mistyczna, czy raczej mistyka filozoficzna? Założenia antropologiczne mistyki i filozofii Karola Wojtyły”, Kultura i Wartości 11 (2015), 1: 5-20. Kultura i Wartości. Kwartalnik internetowy, dostęp 29.02.2019), http://kulturaiwartosci.umcs. lublin.pl/ wp-content/uploads/2011/11/Kazimierz_Rynkiewicz_Filozofia_mistyczna_czy_raczej_ mistyka_filozoficzna.pdf

Stein, Edyta. „Drogi poznania Boga”. W: EAdem. Drogi poznania Boga. Studium o Dionizym Areopagicie i przekład jego dziet. Przełożył Grzegorz Sowiński, 53-161. Kraków: Wydawnictwo Karmelitów Bosych, 2006.

STRZELCZYK, Grzegorz. „Fenomen mistyki”. W: Mistyka chrześcijańska, red. Janusz Wilk, 1123. Katowice: Księgarnia św. Jacka, 2015.

SudBrack, Joseph. Mistyka. Przełożył Bernard Białecki. Kraków: WAM, 1996.

SzTAJER, Sławomir. „Prywatny i publiczny język mistyki”. W: Filozofia religii. T. 5: Mistyka jako stan świadomości i typ doświadczenia religijnego, red. Józef Baniak, 109-124. Poznań: Wydawnictwo UAM, 2009.

Wiseman, James. Historia duchowości chrześcijańskiej. Przełożył Andrzej Wojtasik. Kraków: WAM, 2009.

WszoŁeK, Stanisław. Wprowadzenie do filozofii religii. Kraków: WAM, 2004.

\section{MIĘDZY DOŚWIADCZENIEM A TEORIĄ, CZYLI O NIEKTÓRYCH PROBLEMACH FILOZOFII MISTYKI}

\section{Streszczenie}

Mistyka to dziś nie tylko popularny termin, którym określa się zjawiska często dziwne i niezrozumiałe, oscylujące między psychologią a duchowością. Mistyka to również problem badawczy, którym od dawna zajmują się specjaliści z rozmaitych dyscyplin naukowych. Swój wkład w badania nad mistyką wnosi także filozofia, co więcej - można również postawić tezę, że posiada ona do tego szczególne kompetencje. Nie ulega wątpliwości, że mistyczna intuicja towa- 
rzyszy filozofom niemal od zawsze, a sama fillozofia od samego początku rozwijała się także, tu i ówdzie, jako filozofia mistyczna. Aktualnie uwaga filozofów zajmujących się mistyką koncentruje się głównie na problemach wyznaczonych przez filozofię mistyki — tu toczą się najważniejsze dyskusje i ogniskują spory, zwłaszcza tak zwany spór między esencjalizmem a kontekstualizmem. Autor artykułu stawia tezę, że umiarkowany kontekstualizm, jako stanowisko optujące za istnieniem kilku niesprowadzalnych do siebie typów doświadczeń określanych dziś jako mistyczne, lepiej wyjaśnia złożony fenomen mistycyzmu niż redukcyjne nastawienie esencjalistyczne. Nie znaczy to jednak, że daje wyjaśnienie wyczerpujące. Chociaż omawiany w artykule spór nie wydaje się możliwy do jednoznacznego rozstrzygnięcia, fillozoficzna analiza głównych, konstytuujących go wątków pozwala lepiej zrozumieć naturę kluczowych, rządzących szeroko rozumiana mistyką procesów. Celem niniejszego artykułu jest zatem rozpoznanie sposobu, w jaki filozofia wkracza na teren mistyki, wkładu, jaki wnosi w analizę doświadczenia mistycznego, a także kilku głównych problemów metodologicznych, na które napotyka.

\section{BETWEEN EXPERIENCE AND THEORY, OR ABOUT SOME PROBLEMS OF THE PHILOSOPHY OF MYSTICISM}

Su m mary

Mysticism today is not only a popular term often referred to the strange and incomprehensible phenomena, oscillating between psychology and spirituality. Mysticism is also a research problem, which has long been analyzing by the specialists from various scientific disciplines. Philosophy also has its own contribution to the study of mysticism. Moreover, one can also put forward the thesis about its special competencies for this. There is no doubt that a mystical intuition accompanies the philosophers from the very beginning, and for a long time the philosophy itself has been also developing, here and there, as a mystical philosophy. Currently, the attention of philosophers dealing with mysticism is mainly focused on problems determined by the philosophy of mysticism. Here the most important discussions and disputes are taking place - especially the so-called dispute between essentialism and contextualism. The author of the article formules the thesis that moderate contextualism, as the position that opts for the existence of several irreversible types of experiences defined today as mystical, better explains the complex phenomenon of mysticism than the reductionist essentialist attitude. This does not mean, however, that it gives an exhaustive explanation. Although the dispute examined in the article does not seem to be possible to unambiguously settle, the philosophical analysis of the most important, constitutive themes allows us to better understand the nature of the main processes that shape the broadly understood mysticism. The purpose of this article is therefore to identify the way in which philosophy enters the area of mysticism, the contribution it makes to the analysis of the mystical experience, as well as several major methodological problems that it encounters.

Słowa kluczowe: mistyka; doświadczenie; zjawisko; duchowość; teoria.

Key words: mysticism; experience; phenomenon; spirituality; theory.

Information about Author: Dr. hab. ALEKSANDER RYSZARD BAŃKA, prof. at UŚ - University of Silesia in Katowice, Faculty of Humanities, Institute of Philosophy; address for correspondence: ul. Bankowa 11, 40-007 Katowice; e-mail: aleksander.banka@us.edu.pl; ORCID: https://orcid.org/0000-0003-1801-4710. 